\section{Development of a new Action Plan for the European bison}

The current Action Plan for the European bison (also known as wisent) was published in 2004 following a significant decrease of the population during the 1990s. Since then some of the Plan's aims have been achieved. The main success was the increase from $<3,000$ in 2000 to c. 7,000 by 2017. Nevertheless, a number of problems related to the species' future remain unresolved: an extremely narrow gene pool, loss of the Y chromosome, hybridization with American bison, health threats (new diseases and epidemics have been recorded), limited living space, isolation, poaching and insufficient habitat for reintroduction.

New problems are also emerging, mainly related to the management of this species. As a result of high numbers in some forests, bison damage crops and forest, potentially impairing support for conservation activities amongst local communities (European Journal of Wildlife Research, 2018, 64, 61). The effectiveness of management for this species is limited by differences in the legal status of the species and the approach to European bison conservation amongst European countries, and by the lack of separate procedures for the management of free, semi-free and captive animals. In addition, transfer of animals between breeding centres or free herds is time-consuming and problematic because the formal requirements for the relocation of the European bison remain similar to those for domestic cattle.

Considering all these dilemmas, a special meeting of the Bison Specialist Group of IUCN (European branch) and the European Bison Conservation Centre was held on 6 September 2018 in Muczne, Poland. During the meeting representatives of 11 European countries (Belarus, Bulgaria, Czech Republic, Germany, Lithuania, Netherlands, Poland, Romania, Russia, Spain and Sweden) discussed the current problems of European bison conservation. The threats identified were the improper legal status of the species, lack of societal education about European bison, negative human-bison interactions, misunderstandings related to the environmental requirements of the species, and insufficient knowledge of the species' ecology, distribution, genetics and health problems. Participants agreed that the current Action Plan is out of date and that a revised Action Plan should be prepared as soon as possible.

Members of the Bison Specialist Group and the European Bison Conservation Centre that were present at the meeting have created small international groups responsible for development of particular chapters of the new Action Plan. Health problems will be examined in a separate chapter and a greater emphasis will be placed on issues related to the management of the European bison population, including the human dimensions of this. Drafts of all chapters are expected to be ready in March 2019. If necessary, a new meeting will be arranged for April 2019. The final version of the new Action Plan is expected to be completed by June 2019 .

WANDA OlECH (๑ orcid.org/0000-0002-6166-3954) and

DANIEL KLICH (๑ orcid.org/0000-0001-6276-2316)

Department of Genetics and Animal Breeding, Warsaw

University of Life Sciences, Warsaw, Poland

E-mailwanda_olech@sggw.pl

KateTan PerZanowsKi (@ orcid.org/0000-0002-7988-2194)

The John Paul II Catholic University of Lublin, Institute of Landscape Architecture, Lublin, Poland

\section{The Indonesia-Norway REDD+ Partnership}

Indonesian forests and peatlands continue to be degraded by forces that cannot easily be steered or slowed. They are now also vulnerable to a changing climate and the fire-proneness of damaged and desiccated ecosystems. Hence it is hard to reduce greenhouse gas emissions from land use, or to increase the security of biodiversity, natural ecosystems and traditional lifeways, all of them vital to the process of reducing emissions from deforestation and forest degradation (commonly referred to as REDD+). In 2009 Indonesia and Norway recognized each other as potential REDD+ partners, Indonesia having extensive forests and peatlands, and high land-use emissions that its government wished to reduce, and Norway being keen to support tropical REDD+. They signed a Letter of Intent on 26 May 2010, with Indonesia agreeing to attempt forestry reforms and Norway promising up to USD 1 billion to facilitate and reward success. The Letter of Intent envisioned three phases: Phase 1 for establishing institutions and capacity, Phase 2 for transforming forest management and governance, and Phase 3 for delivering verified emission reductions. All were expected to be complex and challenging, to involve many stakeholders and relationships, and to be marked by slow directional change over a long period.

Former President Yudhoyono appointed REDD+ task forces for Phase 1, and their performance was reviewed in 2011 and 2013 (J. Caldecott, 2017, Aid Performance and Climate Change, Routledge). The reviews confirmed rapid progress: on a moratorium on new forest concessions for logging and plantations in primary forests; on national and subnational REDD+ strategies; on a publicly-accessible database (One Map) with 85 data layers, including all forests, peatlands and concessions (tanahair.indonesia.go.id/portalweb); and on establishing a ministerial-level REDD+ Agency. The latter was set up in August 2013, and led the Letter of Intent process until early 2015. Then the newlyelected President Widodo merged the ministries of environment and forestry as the Ministry of Environment and Forestry, which would absorb the REDD+ Agency and disperse its responsibilities throughout the new institution. The 
challenges of uniting these ministries caused a loss of Phase 2 momentum during 2015-2016 (as well as the 'widespread dismay, both within Indonesia and internationally' noted by Shiv Someshwar in Oryx, 2018, 52, 592).

Later in 2015, however, forest and peatland fires caused immense damage throughout Indonesia and led to a strong response in the form of new and enhanced regulations, a new Peatland Restoration Agency, and increased policy priority for fire prevention, One Map, law enforcement, social forestry and land reform. Thus, ecological reality forced back onto the policy agenda many issues that the REDD+ Agency had been addressing. The Letter of Intent remained in place and was automatically renewed at the end of 2016, and Norway continued to support its Indonesian partners by such means as funding the new Peatland Restoration Agency and delivering capacity-building support to the Ministry of Environment and Forestry, and others. The Partnership remained alive, therefore, although events delayed the third review of the whole process until August 2018 (J. Caldecott et al., 2018, regjerin gen.no/contentassets/56473ac483ff 4 f8fa537bd5dfda9d57b/

idn-nor-third-review--final-report.pdf).

The 2018 review found that Ministry of Environment and Forestry capacity was increasing in many ways, that the moratorium on forest licences had been extended in duration and coverage to include peatland, and that a national monitoring, reporting and verification system for REDD+ was within reach, as was an agreed financing mechanism for REDD+ investments and rewards. Meanwhile, sub-national alliances on low-carbon development among local, provincial and national stakeholders were active, One Map remained government policy and was nearing completion, and forest sector law enforcement was improving. The official recognition of traditional land rights had been slow, but there was a new ministerial task force to accelerate it. There had also been a measurable downturn in the rate of tree cover loss in 2017 compared with 2016. This led the Partners to announce the start of Phase 3 of the Partnership on 16 February 2019, with the commitment of a first payment for delivery of c. 5 million $t$ of emission reductions relative to their agreed ten-year baseline (regjeringen.no/no/aktuelt/redusertavskoging-i-indonesia-utloser-forste-klimautbetalingfra-norge/id2629504/).

JULIAN CALDECOTT Schumacher Institute, and Creatura Ltd, Bath, UK.E-mail julian@creatura.com 